\title{
PEMBELAJARAN ONLINE SEBAGAI BENTUK PENGUATAN PENDIDIKAN SELAMA PANDEMI COVID-19 DI SD MUHAMMADIYAH 03 KOTA MEDAN
}

\section{OLEH:}

\author{
EKO FEBRI SYAHPUTRA SIREGAR ${ }^{1}$ EVA DAMILIA ${ }^{2}$ \\ (UNIVERSITAS MUHAMMADIYAH SUMATERA UTARA ${ }^{1,2}$ )
}

\begin{abstract}
Covid 19 Pandemic brought change in every field without exception the education sector, especially learning that occurred in elementary schools. This study aims to describe the strengthening of education during the covid-19 pandemic at SD Muhammadiyah 03 Medan City, activities carried out by students while studying online at home, various obstacles that students may face in online learning activities and efforts made in overcoming various obstacles students face during online learning. This type of research is qualitative research. The type of data in this study is qualitative data. The results of this study in the form of mandatory activities in the form of online learning by SD Muhammadiyah 03 Medan students who use the WhatsApp application in carrying out teaching and learning activities online. The learning activity in question starts with filling in attendance / attendance, asking news / checking the situation of students, giving directions before giving assignments, doing assignments and collecting assignments according to the schedule and hours specified. This activity is one of the solutions that can be done in elementary schools in carrying out teaching and learning activities online with the hope that students will continue to learn even if they have to be at home.
\end{abstract}

Keywords: Online Learning, Strengthening Education, Covid-19

\section{PENDAHULUAN}

Coronavirus Disease-19 (COVID-19) atau yang lebih dikenal dengan virus corona merupakan keluarga besar virus yang menyebabkan infeksi saluran pernapasan yang bersifat ringan maupun sedang, seperti penyakit flu. Virus ini telah melanda berbagai negara termasuk Indonesia. Siapa pun dapat terinfeksi virus corona tidak peduli golongan muda maupun tua. Berbagai upaya terus dilakukan Pemerintah agar segera dapat mengakhiri masa pandemi COVID-19 di bumi pertiwi ini. Salah satu upaya adalah dengan cara menanamkan pola hidup 
bersih dan sehat dengan rajin mencuci tangan, menggunakan masker dan menjaga jarak atau social distancing hingga Pembatasan Sosial Berskala Besar (PSBB). Hal ini tentunya bertujuan untuk mencegah meluasnya penyebaran wabah ini.

Kementerian Pendidikan dan Kebudayaan Republik Indonesia (Kemendikbud RI) dalam menyikapi hal tersebut kemudian mengeluarkan Surat Edaran Nomor 4 Tahun 2020 tentang Pelaksanaan Kebijakan Pendidikan dalam Masa Darurat Penyebaran Coronavirus Disease (Covid-19). Salah satu poin penting yang terdapat dalam surat edaran tersebut adalah pemberlakuan kegiatan belajar mengajar dari rumah atau pembelajaran daring / jarak jauh bagi guru dan siswa. Sehingga aktivitas pembelajaran di sekolah diliburkan dan proses belajar mengajar berpindah dari sekolah menjadi di rumah. Siswa dan guru harus berkolaborasi dalam pelaksanaan pembelajaran secara maya atau online yang dilakukan melalui belajar mandiri di rumah dengan dampingan orang tua. Hal ini menjadi solusi agar pendidikan terus mendapatkan perhatian dan tidak mengurangi kebermaknaan proses belajar mengajar selama pembelajaran online berlangsung guna mewujudkan SDM Unggul Indonesia Maju. Maka dari itu diperlukan adanya penguatan pendidikan selama berlangsungnya Social Distancing. Guru dan orang tua harus berkolaborasi dalam melakukan penguatan pendidikan tersebut.

Pendidikan merupakan usaha mempersiapkan siswa agar dapat tumbuh kembang secara baik dan mampu beradaptasi dengan berbagai situasi dan kondisi yang dihadapi dalam menjalankan kehidupnya. Hal tersebut sesuai dalam Undang-Undang No. 20 Tahun 2003 tentang sistem pendidikan nasional dalam pasal 1 ayat (1) yang disebutkan bahwa pendidikan adalah usaha sadar dan 
terencana untuk mewujudkan suasana belajar dan proses pembelajaran agar anak didik secara aktif mengembangkan potensi dirinya untuk memiliki kekuatan spiritual keagamaan, pengendalian diri, kepribadian, kecerdasan, akhlak mulia, serta keterampilan yang diperlukan dirinya, masyarakat, bangsa dan negara. Maka dari itu pendidikan harus terus dipertahankan meski wabah covid-19 ini sedang melanda.

Berdasarkan hasil observasi dan wawancara yang dilakukan di SD Muhammadiyah 03 Kota Medan menunjukan bahwa penguatan pendidikan selama pandemi covid-19 di lingkungan rumah diterapkan dengan cukup baik, yaitu terlihat dengan dilaksanakannya pembelajaran online dan adanya berbagai aktivitas yang ditandai dengan kegiatan absensi, menanyakan kabar/mengecek keadaan siswa, memberikan pedoman atau arahan sebelum memberikan tugas, mengerjakan tugas, dan mengumpulkan tugas sesuai jadwal dan jam yang sudah ditentukan sebagai bentuk penguatan pendidikan. Maka perlu diadakan penelitian yaitu Belajar Online Sebagai Bentuk Penguatan Pendidikan Selama Pandemi Covid-19 oleh SD Muhammadiyah 03 Kota Medan.

\section{METODE PENELITIAN}

Penelitian ini merupakan jenis penelitian kualitatif. Adapun jenis data yang digunakan dalam penelitian ini yaitu data kualitatif. Data yang dibutuhkan dalam penelitian ini diambil melalui observasi yang dilakukan pada salah seorang guru di SD Muhammadiyah 03 Kota Medan yang menerapkankan kegiatan belajar mengajar secara online dengan menggunakan aplikasi WhatsApp. Selain itu, pemerolehan data dilakukan dengan cara wawancara dengan kepala sekolah, guru, 
dan siswa serta adanya dokumentasi berupa gambar, tulisan dan video untuk merekam kegiatan penelitian. Teknik pengolahan data dilakukan dengan cara reduksi data, display data serta verifikasi data. Pada tahapan reduksi data, peneliti melakukan pemilihan terkait data yang diperoleh baik pada saat observasi, wawancara maupun kegiatan dokumentasi. Sedangkan tahapan display data yaitu menggabungkan berbagai data maupun informasi yang diperoleh saat kegiatan berlangsung. pada tahapan akhir yaitu verifikasi data, yaitu menarik kesimpulan dari data yang diperoleh untuk menjawab rumusan masalah yang sudah ditetapkan.

\section{HASIL PENELITIAN}

\section{PEMBAHASAN}

Pembelajaran online merupakan salah satu wujud dari upaya penguatan pendidikan selama diberlakukannya Social Distancing. Belajar online dapat dilakukan dengan memanfaatkan teknologi informasi dan komunikasi, seperti media komputer dengan berbantuan jaringan internet, telepon maupun fax. Pemanfaatan media ini bergantung pada struktur materi pembelajaran dan tipetipe komunikasi yang diperlukan. Salah satu perangkat yang mudah digunakan dan bersifat fleksibel saat pembelajaran online adalah handphone. Didalam handphone dapat banyak menampung berbagai aplikasi pembelajaran yang dapat mendukung kegiatan belajar online seperti Google Cllassroom, Edmodo, Quizziz, Ruang Guru, Sekolahmu, Zenius, Zoom, Kelas Pintar, WhatsApp serta berbagai aplikasi lainnya.

Di SD Muhammadiyah 03 Medan, dalam pembelajaran online cenderung menggunakan aplikasi WhatsApp dikarenakan aplikasi ini sangat ramah dan 
hampir ada pada setiap smartphone orang tua siswa. Hal yang dapat diajadikan alasan lainnya yaitu kualitas handphone ataupun smartphone yang dimiliki orang tua siswa juga menjadi penentu keberlangsungan pembelajaran, sehingga dengan menggunaan WhatsApp orang tua tidak perlu melakukan download aplikasi lainnya agar kecepatan handphone menjadi tidak lambat.

Melalui WhatsApp, para guru dapat mengirimkan materi baik berupa bahan presentasi dalam bentuk powerpoint, link materi yang akan dijadikan rujukan ataupun tambahan bahan bacaan selain buku, link youtube dalam pengamatan video serta ruang diskusi dalam bentuk chat maupun pesan suara (voice note) dalam menyampaikan arahan terkait pembelajaran yang akan dilaksanakan. Dalam hal pembelajaran yang menuntut adanya kegiatan dari siswa berupa praktikum, para guru biasanya meminta para orang tua untuk merekam atau mendokumentasikan aktivitas siswa dalam bentuk video dan kemudian dikirimkan dalam grup WhatsApp ruang kelas mereka.

Untuk lebih jelasnya, berikut adalah aktivitas yang biasa dilakukan oleh siswa bersama guru dalam kegiatan pembelajaran online melalui aplikasi WhatsApp, yaitu :

\section{a. Mengisi daftar kehadiran/absensi}

Kegiatan ini sama halnya dengan proses pembelajaran yang biasa dilakukan saat tatap muka di sekolah yaitu mengecek kehadiran siswa sebelum memulai pembelajaran. Kegiatan ini merupakan kegiatan awal yang dilakukan oleh siswa sebelum pembelajaran dimulai setelah bergabung di grup online kelas yang sudah dibuat oleh guru. Orang tua dapat membantu siswa pada saat mengisi kehadiran/absensi. Jika sampai batas waktu yang sudah ditentukan tidak 
mengisi/bergabung dalam grup kelas maka siswa tersebut dinyatakan tidak hadir. Peran orang tua sangat membantu dalam keberlangsungan pembelajaran online ini.

\section{b. Menanyakan kabar/mengecek keadaan siswa}

Setelah mengecek kehadiran siswa SD Muhammadiyah 03 Kota Medan guru kelas menanyakan keadaan ataupun kabar siswa. Hal ini untuk mengetahui keadaan, kesehatan maupun kesiapan siswa dalam megikuti pembelajaran yang akan dilaksanakan. Apabila ditemukan terdapat siswa yang sedang sakit, maka siswa tersebut tidak dibenarkan mengikuti proses pembelajaran online dan dianjurkan untuk beristirahat. Kemudian orang tua siswa dapat menghubungi guru kelas jika memang anaknya sedang sakit lalu guru kelas bisa menjelaskan tugas apa saja yang akan dikerjakan dan batas pengumpulan tugas kepada orang tua siswa.

\section{c. Memberi arahan sebelum memberikan tugas}

Sebelum guru kelas memberikan tugas kepada siswa, guru terlebih dahulu memberi arahan dan maksud dari pembelajaran yang akan dilaksanakan. Maka dari itu siswa diarahkan untuk membaca materi yang ada pada buku pegangan/pelajaran agar nantinya mudah untuk menyelesaikan tugas yang akan diberikan. Pada saat ini guru juga bisa menjelaskan apa yang kiranya perlu dijelaskan dan menanyakan apakah siswa sudah memahami tugas yang diberikan. 


\section{Gambar. 1 Guru Memberikan Arahan Terkait Pembelajaran}

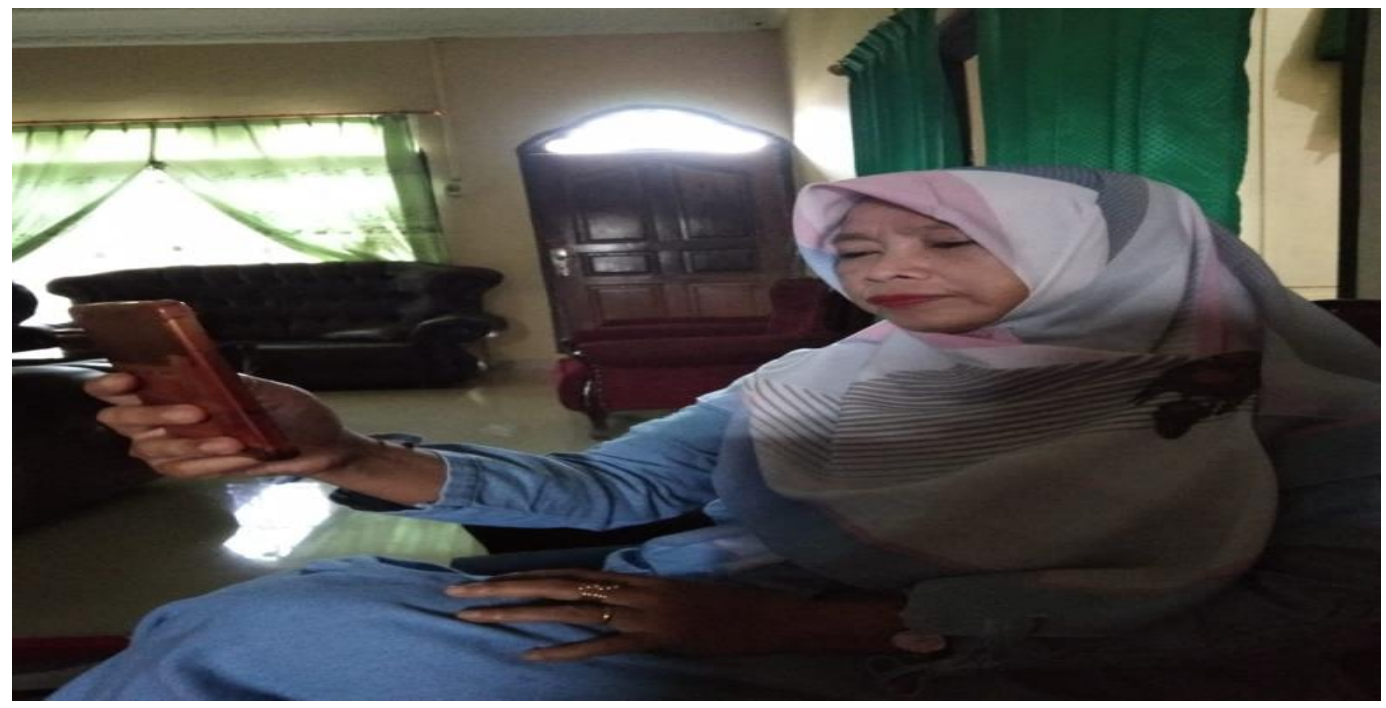

\section{d. Mengerjakan tugas}

Setelah selesai memberikan arahan maupun penjelasan materi, siswa kemudian diberikan tugas dan wajib dikerjakan. Orang tua siswa kemudian diminta untuk mendokumentasikan aktivitas belajar anak khususnya saat mengerjakan tugas. Dokumentasi foto tersebut akan menjadi bukti bahwasannya siswa benar-benar mengerjakan tugas yang diberikan guru kelas. Orang tua juga diperbolehkan untuk menemani dan membantu anaknya pada saat mengerjakan tugas di rumah.

\section{Gambar 2. Aktivitas Siswa saat Mengerjakan Tugas}

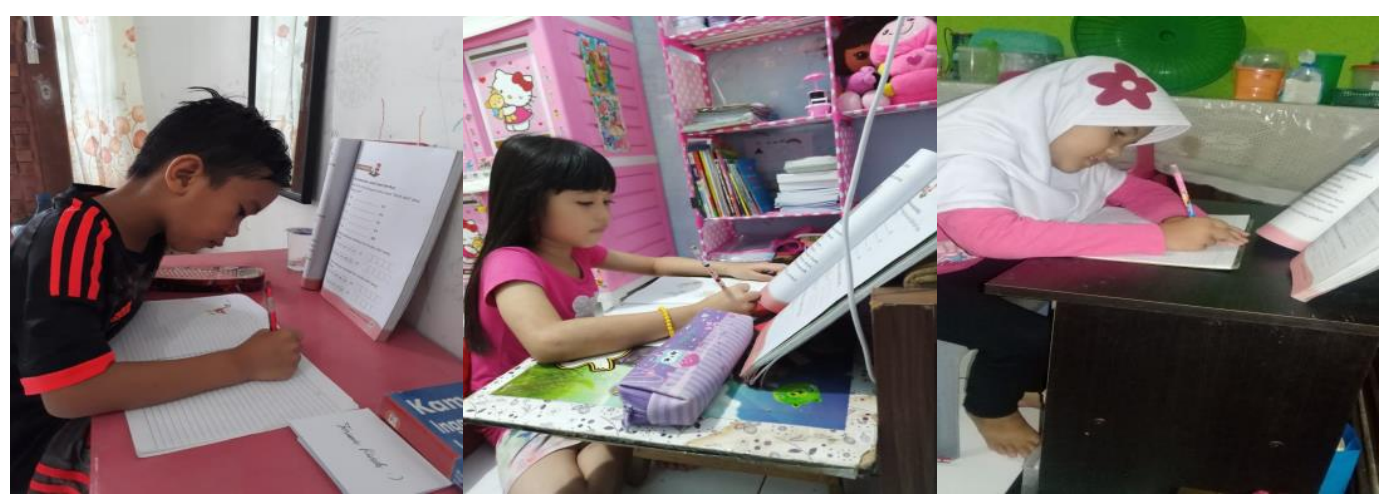




\section{e. Mengumpulkan Tugas dan Penilaian}

Setelah siswa/i SDS Muhammadiyah 03 Kota Medan selesai mengerjakan tugas, orang tua siswa/i diminta untuk mengirimkan tugas lewat WhatsApp atau grup online yang sudah di buat guru. Guru juga memberikan batasan waktu pengumpulan tugas agar semua terkumpul secara rata dan mempermudah guru untuk mengkoreksi/menilai tugas yang sudah dikerjakan siswa. Secara garis besar kriteria penilaian tugas siswa dalam pembelajaran online yang diterapkan, yaitu kesesuaian jawaban dengan materi yang dibahas, kerapian tulisan serta ketepatan waktu dalam mengirimkan tugas.

Pembelajaran online dalam situasi pandemi Covid-19 tentunya memberikan kelebihan tersendiri bagi guru dan siswa SD Muhammadiyah 03 Medan diantaranya; 1) melatih siswa untuk menanamkan kebiasaan belajar secara mandiri sehingga tidak bergantung pada guru atau temannya; 2) dapat mengembangkan kreativitas siswa dan memberikan kebebasan dalam mencari informasi pada saat mengerjakan tugas; 3) meningkatkan kedisiplinan siswa karena memiliki jadwal yang telah ditetapkan dan 4) mengajarkan siswa untuk menghargai waktu.

Disamping kelebihan, tentunya terdapat kekurangan ataupun beberapa kendala yang dihadapi dalam pelaksanaan pembelajaran online di SD Muhammadiyah 03 Medan, diantaraya; 1) Masih adanya beberapa orang tua yang belum terampil dalam menggunakan handphone maupun aplikasi yang dimiliki, sehingga pembelajaran online belum maksimal; 2) Jaringan/ signal menjadi penentu keberhasilan pembelajaran online, sehingga ketika terjadi permasalahan mengakibatkan pembelajaran menjadi tidak efektif dan berdampak pada materi 
yang disampaikan; 3) Durasi waktu belajar serta kuota paket internet yang mengakibatkan pembelajaran menjadi lebih singkat; 4) Guru tidak dapat memantau secara langsung perkembangan siswa selama belajar online dan 5) Sosialisasi siswa antar guru dan teman-temannya menjadi berkurang.

\section{PENUTUP}

Belajar online yang dilakukan merupakan wujud pelaksanaan penguatan pendidikan selama pandemi covid-19 melanda Indonesia yang dilakukan oleh SD Muhammadiyah 03 Kota Medan. Disekolah ini pembelajaran tetap berlangsung walaupun berpindah dari pembelajaran yang seharusnya dilakukan di sekolah (tatap muka) bergeser menjadi pembelajaran di rumah (online)hal ini dikarenakan guna mengurangi penyebaran wabah Covid-19 yang berakibat pada ditutup/diliburkan sekolah. Adapun kegiatan pembelajaran online yang dilakukan meliputi ; 1) Mengisi kehadiran/absensi; 2) Menanyakan kabar/mengecek keadaan siswa; 3) Memberi arahan sebelum memberikan tugas; 4) Mengerjakan tugas, dan 5) Mengumpulkan tugas sesuai jadwal dan jam yang sudah ditentukan dan penilaian.

Dalam pelaksanaan kegiatan belajar online tersebut tentu terdapat kendala. Namun hal tersebut tidak menjadi masalah yang besar bagi kepala sekolah dan guru yang mengajar di SDS Muhammadiyah 03 Kota Medan. Peran guru dan orang tua juga sangat berpengaruh dalam mengatasi kendala pelaksanaan belajar online dalam pengutan pendidikan selama pandemic covid-19. 


\section{DAFTAR PUSTAKA}

Abidin, Zainal. 2020.Pembelajaran Online Berbasis Proyek Salah Satu Solusi Kegiatan Belajar Mengajar Di Tengah Pandemi Covid-19. Jurnal Ilmiah Profesi Pendidikan.(5). (1).

Fadli, Rizal. 2020. Coronavirus. https://www.halodoc.com/kesehatan/coronavirus (Diakses pada 11 Juni 2020)

Kusmana, Suherli. 2016. Merancang Karya Tulis Ilmiah. Bandung : PT. Remaja Rosdakarya Offset

Menteri Pendidikan. (2020). Surat Edaran Nomor 3 Tahun 2020 Tentang Pelaksanaan Pendidikan dalam Masa Darurat CoronaVirus (COVID-19).

Sugiyono. (2012). Metode Penelitian Kuantitatif Kualitatif dan R\&D. Alfabeta.

Wahyu Aji Fatma Dewi.2020. Dampak COVID-19 terhadap Implementasi Pembelajaran Daring di Sekolah Dasar. EDUKATIF Jurnal Ilmu Pendidikan Faculty of Education : University of Pahlawan Tuanku Tambusai

Yurianto, Ahmad, Bambang Wibowo, K. P. (2020). PEDOMAN PENCEGAHAN DAN PENGENDALIAN CORONAVIRUS DISEASE (COVID-19) (M. I. Listiana Azizah, Adistikah Aqmarina (ed.)). 